\title{
Abundance of soil microbes, endophytic fungi and blast disease of paddy rice with three pest management practices
}

\author{
SURYO WIYONO ${ }^{\natural}$, BONJOK ISTIAJI, HERMANU TRIWIDODO, ANDIKA S. SURYANINGSIH \\ Department of Plant Protection, Faculty of Agriculture, Institut Pertanian Bogor. Jl. Kamper, Kampus IPB Darmaga, Bogor 16680, West Java, Indonesia. \\ Tel.: +62-251-8629364, Fax.: +62-251-8629362, ^email: suryowi@apps.ipb.ac.id
}

Manuscript received: 23 June 2020. Revision accepted: 23 August 2020.

\begin{abstract}
Wiyono S, Istiaji B, Triwidodo H, Suryaningsih AS. 2020. Abundance of soil microbes, endophytic fungi and blast disease of paddy rice with three pest management practices. Biodiversitas 21: 4234-4239. Rice production in Indonesia faces a potential threat of pests and diseases. Biointensive Integrated Pest Management (Bio IPM) is a new approach based on natural and biological control, which effectively controls pests and diseases. However, the impact of this technology on soil microbes and endophytic fungi is almost unknown. The objective of the study was to investigate the effect of Bio IPM on abundance of soil microbes, endophytic fungi, and blast disease under field conditions. Three pest management types were tested i.e. conventional, reduced pesticides, and Bio IPM. Field experiment was set in four replications in randomized complete block design. Experiments were carried out in two seasons i.e. dry and wet season. Variables assessed during experiment were amount of soil bacteria, soil fungi, phosphate solubilizing bacteria, colonization of total leaf endophytes, colonization of Nigrospora sp., and blast disease severity. The results showed that the abundance of soil bacteria and phosphate solubilizing bacteria were significantly increased with Bio IPM whereas it was not found to be significant in soil fungi. Total endophytic fungi and Nigrospora sp. were found higher in Bio IPM especially in early growth stages. Bio IPM controlled neck blast more effectively than conventional and reduced pesticides, but it did not show any significant effect on leaf blast disease.
\end{abstract}

Keywords: Bio IPM, endophytes, Nigrospora, neck blast, paddy rice, PGPR, soil microbiology, straw amendment

\section{INTRODUCTION}

Rice production in Indonesia faces a serious problem of pests and diseases, threatening the national rice supply. The estimated loss of rice yield due to pests and diseases in Southeast Asia is $27.7 \%$ (Oerke and Dehne 2004). The annual rice grain production of Indonesia is 56.5 million tons (BPS-Statistics Indonesia 2019), and the estimated loss of rice yield is 62.6 trillion rupiahs. Therefore, effective pest management is an essential key to secure national rice production. The problem of pests and diseases of rice related to a fragile rice field agroecosystem. Various studies have shown that the use of pesticides in rice in Indonesia is very high, 11 sprays/seasons in Karawang, 12 sprays/seasons in Klaten and Tegal (Hidayat et al. 2010; Istiaji et al. 2012). This has weakened the resilience of paddy ecosystems due to the death of insect natural enemies, and in addition, has damaged complex food webs in rice fields agroecosystem (Settle et al. 1996; Park and Lee 2009).

In last twenty years, most of the rice biomass is straw, which has gone out from the paddy fields in Java. This leads to a continuous decrease in soil organic matter, and consequently causing depletion of diversity and abundance of detritivores and decomposers (Settle et al.1996). In addition, it causes loss of valuable nutrients like N, P, K, $\mathrm{Ca}, \mathrm{Mg}, \mathrm{Si}$, and microelements. Without $\mathrm{K}$, application of fertilizers using $\mathrm{N}$ and $\mathrm{P}$ alone worsen nutrients imbalance. Study of Husnain et al. (2010) on paddy field in northern coast of Java Island, Indonesia concluded a negative balance on potassium and silicate of this area. These two nutrients play important role in the rice resistance against pests and diseases.

Due to overuse of pesticides, continuous straw outflow, and insufficient application of potassium fertilizer lowland rice agroecosystems in Java become a fragile farming system, which is susceptible to the outbreak of destructive pests such as brown planthopper, stem borer, and blast disease. Data from the Center for Agricultural Data and Information System of Agriculture-Secretariat General Ministry of Agriculture (2015), shows that the area affected by rice blast disease has increased 13 times since 2009 . Another notorious pest, the brown planthopper (BPH) caused repeated severe outbreak in 1974, 1986, 1998, 2010, and 2017.

The Department of Plant Protection Faculty of Agriculture IPB University has developed Biointensive Integrated Pest Management (Bio IPM), an integration of the best techniques in managing pests and diseases of rice, based on optimization of biological and natural control. Bio IPM technology includes (i) straw amendment, (ii) optimizing NPK and compost tea application, (iii) application of plant growth-promoting rhizobacteria/PGPR and endophytic Nigrospora sp., (iv) zero use of synthetic pesticides. It has been tested under field conditions, that Bio IPM was able to effectively control stem borer, brown planthopper, and blast diseases (Wiyono et al 2014).

Individual treatment of Bio IPM component has been studied on rice pests, diseases, and arthropods community in Indonesia. Organic material amendment on rice fields 
and zero pesticide uses may increase the complexity of food webs in the paddy agroecosystem, and may be resulting in reducing pests infestation (Settle et al 1996). Moreover, PGPR treatment has been proven to reduce blast disease by up to $70 \%$ (Handoko et al. 2009). In addition, the use of endophytic Nigrospora sp. was able to control brown planthopper disease very effectively (Wiyono et al. 2011; Mawan et al. 2015).

However, no data are available on the effects of Bio IPM on soil microbes, leaf endophytic fungal abundance, and blast disease under field conditions. The objective of this research is to determine the abundance of soil microorganisms, leaf endophytes with Bio IPM treatment, and the impact of Bio IPM technology packages in controlling blast disease has also been investigated.

\section{MATERIALS AND METHODS}

The study was conducted in Sumberjaya Village, Tempuran Sub-district and, Karawang District, West Java, Indonesia in two seasons, once at dry season (July 2014October 2014) and once at wet season (December 2014March 2015). The study consisted of three treatments were (i) conventional treatment, (ii) reduced pesticides, and (iii) BioIntensive Integrated Pest Management (Bio IPM).

For conventional treatment, NPK compound fertilizer $150 \mathrm{~kg} / \mathrm{ha}+$ Urea $100 \mathrm{~kg} / \mathrm{ha}, \mathrm{SP} 50 \mathrm{~kg} / \mathrm{ha}$ were used in experiment. Carbofuran pesticides were used in nurseries 3 weeks after planting (WAT) with a dose of $600 \mathrm{~g} \mathrm{a} .1 / \mathrm{ha}$. Insecticides such as MIPC at a dose of $1500 \mathrm{~g}$ a.i./ha and fungicide such as difenoconazole at a dose of $75 \mathrm{~g}$ ai./ha were given at weekly intervals from 2 WAT to 8 WAT. Glyphosate herbicide was used at the time of pre-planting, 3 days before planting. In this treatment straw, PGPR and endophytic fungi were not applied.

In Reduced Pesticides treatment, $250 \mathrm{~kg} / \mathrm{ha}$ urea, 150 $\mathrm{kg} / \mathrm{ha} \mathrm{SP}$ and $100 \mathrm{~kg} / \mathrm{ha} \mathrm{KCl}$ were used as fertilizers. The insecticide Buprofezin was applied at recommended dosage i.e. $900 \mathrm{~g}$ ai/ha., when the plant hopper population was > 20 individuals/tiller, based on monitoring, without straw amendment, without PGPR and endophytes. Synthetic chemical fungicides were not applied.

In Bio IPM treatment, seeds were treated by endophytic fungus viz. Nigrospora sp.., isolate of Wiyono et al (2012)., by priming technique. The density of fungus was $10^{6}$ spores/g for 24 hours, coated by plant growth-promoting bacteria (PGPR) $10 \quad 6 \quad \mathrm{cfu} / \mathrm{g}$ containing mixture of Pseudomonas fluorescens and Bacillus polymixa (Widodo and Wiyono 2012); rice straw amendment $5000 \mathrm{~kg} / \mathrm{ha}$ and $200 \mathrm{~kg} / \mathrm{ha}$ manure. Fertilizers such as NPK $250 \mathrm{~kg}$ urea, $150 \mathrm{SP} \mathrm{kg}$, and $100 \mathrm{~kg} / \mathrm{KCl}$ were applied per hectare. In this treatment zero pesticides and foliar application of compost tea at the rate of $15 \mathrm{cc} / \mathrm{L}$ were used at the ages of 2, 4, and 6 WAT.

Each treatment was arranged in a randomized complete block design (RCBD) with four replications in the form of groups. Each trial unit was $400 \mathrm{~m}^{2}$. Rice cv. Mekonga was cultivated with spacing of $25 \mathrm{~cm}$ x $20 \mathrm{~cm}$. Experiment was conducted in two growing seasons i.e. dry season (JulyOctober) and wet season (December-March).

\section{Variable abundance of soil microbe}

The variables observed were total bacteria, total fungi, and total phosphate solubilizing bacteria. Soil samples were taken out from three points per unit, $200 \mathrm{~g}$ per point, and were mixed per replicate. The abundance of microbes was determined by serial dilution followed by plate count method (Biswas et al 2018). Freshly prepared Trypticase Soy Agar (TSA), Potato Dextrose Agar (PDA), and Pikovskaya agar media were used for the enumeration of total bacteria, total fungi and total phosphate solubilizing bacteria respectively (Juma et al. 2018; Suliasih and Widawati 2005). The abundance of soil microbes was expressed in $\log \mathrm{cfu} / \mathrm{g}$ soil. Microbial abundance was assessed twice, first at two weeks after transplanting (2 WAT) represents vegetative growth stage, and second at seven weeks after transplanting (7 WAT)-represents generative growth stage.

\section{Determination of abundance of endophytic fungi and Nigrospora $s p$.}

A total of 3 plants were randomly selected from each replication unit, then taken 3 tillers per hill one leaf was taken from each tiller and brought to laboratory. Each leaf was surface sterilized twice with $70 \%$ alcohol and $1 \%$ $\mathrm{NaOCl}$ and then rinsed with sterilized water and cut into 5 pieces $(0.5 \mathrm{~cm} \times 0.5 \mathrm{~cm})$ per unit then placed on PDA. Endophyte sampling was done at the age of 2, 4, 6, 8, 10 WAT. Colonization of total endophytic fungi was carried out according to the technique of Suryanarayanan and Vijaykrishna (2001). Colonization of total endophytic fungi was calculated based on percentage of segments with fungal endophytes, without considering the species. In addition, abundance of Nigrospora sp. was determined by percentage of samples colonized by the fungus.

\section{Plant growth measurement}

Variables of plant growth observed were plant height (6 WAT), root length (6 WAT), number of tillers (4 WAT), maximum number of tillers (6 WAT), and number of productive tillers ( 8 WAT). Plant height and root length were measured in $\mathrm{cm}$ using ruler. The number of tillers was calculated by counting the number tillers appear at 4 WAT. Maximum number of tillers was calculated at the end of vegetative development when panicle was released or at 6 MST. Meanwhile, productive tillers have been calculated by counting the tillers that have produced panicles when the rice enters generative growth at 8 WAT.

\section{Assessment of blast disease}

Leaf blast was assessed at 2, 4, and 6 WAT, while neck blasts at 9 WAT. Leaf blast was assessed based on IRRI scoring i.e. 0, 1,2,3,4,5,6,7,8,9 (International Rice Research Institute 2002), and then disease severity was calculated by following formula as described by Towsend and Heuberger (1943). Neck blast was assessed by calculating the percentage of panicles affected compared to the total number of panicles. 


\section{Disease severity $=\frac{\text { ¿infection frequencies } x \text { number of plants of each class }}{\text { Total of observed plants } x \text { highest value of the evaluation scale }} \times 100$}

\section{Data analysis}

Data for each season were analyzed statistically separately. The statistical analysis was analyzed through ANOVA using SPSS software 16.0. The variables were processed with ANOVA (Analysis of Variance) and results showed that there was a significant difference between the mean values Tukey test.

\section{RESULTS AND DISCUSSION}

\section{Abundance of soil microbes}

The result showed that types of pest management techniques affected the abundance of soil microbes. Bio IPM improved soil microbiology by increasing the total bacteria and phosphate solubilizing bacteria in the dry season and wet season, but this treatment did not affect the abundance of total soil fungi. Bio IPM leads to total soil bacteria higher and significantly differs from conventional and reduced pesticide treatments at 2 and 7 WAT in both the seasons. The effect of Bio IPM treatment on phosphate solubilizing bacteria was significant at the early growing stage (2 WAT) and middle growing stage (7 WAT) in dry season, but in wet season it was significant at 2 WAT only. Interestingly, reduced pesticide treatment did not show any significant effect on the abundance of total bacteria, total soil fungi and phosphate solubilizing bacteria (Table 1).

\section{Abundance of endophytic fungi}

The abundance of total endophytic fungi was increased with increasing age of rice, it was influenced by pest control techniques. In vegetative growth stages (4-6 WAT), colonization of total endophytic fungi was significantly higher in Bio IPM than in conventional and reduced pesticide treatments. However, at 8 and 10 WAT, colonization rate was very high in all treatments (100\%) and not significantly differ among treatments (Table 2). In Bio IPM treatment the abundance of Nigrospora sp. was significantly higher at vegetative growth stage (4-6 WAT) than in conventional and reduced pesticide treatments
(Table 3). At the older ages (8-10 WAT) the abundance of Nigrospora sp. was not different among treatments (Table 3). Nigrospora sp. has microscopic characteristics, hyaline hyphae, short conidiophore, conidia are single-cell, brownish-black, and oblate spheroid (Figure1).

\section{Blast disease}

The severity of leaf blast in Bio IPM treatment was not significantly different than conventional and reduced pesticides. However, Bio IPM was able to suppressed neck blast disease which indicated a significantly lower neck blast level than other two treatments. The reduced pesticide technique did not show significantly different effects with conventional blast control (Table 4).

\section{Plant growth}

Results indicate that Bio IPM technology significantly affects some aspects of plant growth. It enhanced the maximum number of tillers and the productive tillers but did not affect plant height and root length. The two variables, maximum number of tillers and productive tillers, were higher in Bio IPM than conventional and reduced pesticide techniques (Table 5).

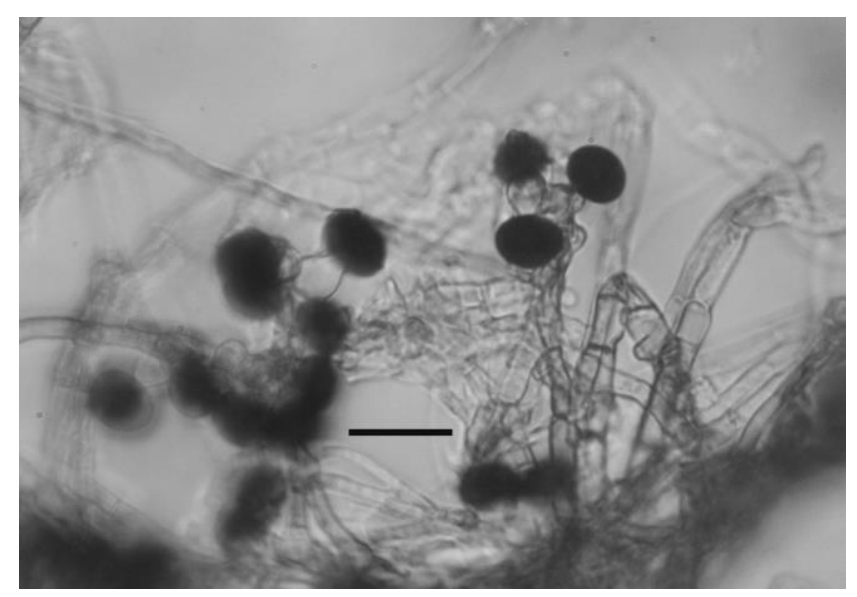

Figure 1. Conidia and conidiophore of Nigrospora $\mathrm{sp} .(\mathrm{bar}=10$ $\mu \mathrm{m})$

Tabel 1. Abundance of soil microbes in three pests management techniques

\begin{tabular}{|c|c|c|c|c|c|c|c|}
\hline \multirow[t]{2}{*}{ Seasons } & \multirow[t]{2}{*}{ Treatment } & \multicolumn{2}{|c|}{$\begin{array}{c}\text { Total soil bacteria abundance } \\
\text { at the age of (WAT) } \\
\text { (log cfu/g soil) }\end{array}$} & \multicolumn{2}{|c|}{$\begin{array}{c}\text { Abundance of soil fungi at } \\
\text { the age of (WAT) } \\
\text { (log cfu/g soil) }\end{array}$} & \multicolumn{2}{|c|}{$\begin{array}{l}\text { Abundance of phosphate } \\
\text { solubilizing bacteria at the } \\
\text { age (WAT) (log cfu/g soil) }\end{array}$} \\
\hline & & 2 & 7 & 2 & 7 & 2 & 7 \\
\hline \multirow{3}{*}{ Dry } & Conventional & $6.39 \mathrm{~b}$ & $6.64 \mathrm{~b}$ & $4.44 \mathrm{a}$ & $4.67 \mathrm{a}$ & $5.57 \mathrm{~b}$ & $5.02 \mathrm{~b}$ \\
\hline & Reduced Pesticide & $6.32 \mathrm{~b}$ & $6.32 \mathrm{~b}$ & $4.49 \mathrm{a}$ & $4.56 \mathrm{a}$ & $5.62 \mathrm{~b}$ & $5.29 \mathrm{a}$ \\
\hline & Bio IPM & $6.68 \mathrm{a}$ & $7.11 \mathrm{a}$ & $4.43 \mathrm{a}$ & $4.59 \mathrm{a}$ & $6.37 \mathrm{a}$ & $5.87 \mathrm{a}$ \\
\hline \multirow{3}{*}{ Wet } & Conventional & $6.34 \mathrm{~B}$ & $6.45 \mathrm{~B}$ & $4.84 \mathrm{~A}$ & $4.89 \mathrm{~A}$ & $4.31 \mathrm{~B}$ & $4.24 \mathrm{~A}$ \\
\hline & Reduced Pesticide & $6.53 \mathrm{~B}$ & $6.73 \mathrm{~B}$ & $5.23 \mathrm{~A}$ & $5.28 \mathrm{~A}$ & $4.34 \mathrm{~B}$ & $5.23 \mathrm{~A}$ \\
\hline & Bio IPM & $6.87 \mathrm{~A}$ & $6.98 \mathrm{~A}$ & $5.41 \mathrm{~A}$ & $5.35 \mathrm{~A}$ & $5.23 \mathrm{~A}$ & $5.65 \mathrm{~A}$ \\
\hline
\end{tabular}

Note: numbers followed by same symbols in same column and same seasons are not significantly different according to Tukeys test at $\mathrm{p}$ $<0.05$ 
Tabel 2. Total endophytic fungi abundance in three pests management techniques

\begin{tabular}{|c|c|c|c|c|c|c|}
\hline \multirow[t]{2}{*}{ Seasons } & \multirow[t]{2}{*}{ Treatments } & \multicolumn{5}{|c|}{$\begin{array}{c}\text { Colonization rate }(\%) \text { at different plant ages } \\
\text { (--week after transplanting/WAT) }\end{array}$} \\
\hline & & 2 & 4 & 6 & 8 & 10 \\
\hline \multirow[t]{3}{*}{ Dry } & Conventional & $4.42 \mathrm{a}$ & $19.25 \mathrm{~b}$ & $69.44 \mathrm{~b}$ & $100 \mathrm{a}$ & $100 \mathrm{a}$ \\
\hline & Reduced pesticides & $3.08 \mathrm{a}$ & $19.25 \mathrm{~b}$ & $63.89 \mathrm{~b}$ & $100 \mathrm{a}$ & $100 \mathrm{a}$ \\
\hline & Bio IPM & $7.22 \mathrm{a}$ & $27.50 \mathrm{a}$ & $88.88 \mathrm{a}$ & $100 \mathrm{a}$ & $100 \mathrm{a}$ \\
\hline \multirow[t]{3}{*}{ Wet } & Conventional & $4.78 \mathrm{~A}$ & $32.5 \mathrm{~B}$ & $80.56 \mathrm{~B}$ & $100 \mathrm{~A}$ & $100 \mathrm{~A}$ \\
\hline & Reduced pesticides & $7.86 \mathrm{~A}$ & $36.43 \mathrm{~B}$ & $77.8 \mathrm{~B}$ & $100 \mathrm{~A}$ & $100 \mathrm{~A}$ \\
\hline & Bio IPM & $7.86 \mathrm{~A}$ & $52.5 \mathrm{~A}$ & $91.67 \mathrm{~A}$ & $100 \mathrm{~A}$ & $100 \mathrm{~A}$ \\
\hline
\end{tabular}

Note: Numbers followed by same symbols in same column and same seasons are not significantly different according to Tukeys test at $\mathrm{p}<0.05$

Table 3. Abundance of endophytic Nigrospora sp. in paddy leaves in three pests management techniques

\begin{tabular}{llccccc}
\hline \multirow{2}{*}{ Seasons } & \multirow{2}{*}{ Treatments } & \multicolumn{4}{c}{ Colonization rate (\%) at different plant ages (--week after transplanting/WAT) } \\
\cline { 3 - 6 } & & $\mathbf{2}$ & $\mathbf{4}$ & $\mathbf{6}$ & $\mathbf{8}$ & $\mathbf{1 0}$ \\
\hline \multirow{2}{*}{ Dry } & Conventional & $4.42 \mathrm{a}$ & $10.75 \mathrm{~b}$ & $33.10 \mathrm{~b}$ & $52.50 \mathrm{a}$ & $67.64 \mathrm{a}$ \\
& Reduced Pesticides & $0 \mathrm{a}$ & $6.50 \mathrm{~b}$ & $33.10 \mathrm{~b}$ & $52.56 \mathrm{a}$ & $57.37 \mathrm{a}$ \\
& Bio IPM & $6.34 \mathrm{a}$ & $23.5 \mathrm{a}$ & $55.56 \mathrm{a}$ & $55.56 \mathrm{a}$ & $63.89 \mathrm{a}$ \\
\multirow{2}{*}{ Wet } & $4.42 \mathrm{~A}$ & $13.75 \mathrm{~B}$ & $60.56 \mathrm{~B}$ & $90.56 \mathrm{~A}$ & $92.56 \mathrm{~A}$ \\
& Conventional & $2.86 \mathrm{~A}$ & $11.50 \mathrm{~B}$ & $57.78 \mathrm{~B}$ & $87.78 \mathrm{~A}$ & $85.78 \mathrm{~A}$ \\
& Reduced pesticides & $6.50 \mathrm{~A}$ & $22.01 \mathrm{~A}$ & $81.67 \mathrm{~A}$ & $91.67 \mathrm{~A}$ & $91.67 \mathrm{~A}$ \\
\hline
\end{tabular}

Note: Numbers followed by same symbols in same column and same seasons are not significantly different according Tukeys test at $\mathrm{p}<0.05$

Table 4. Severity of blast disease in three pests management techniques

\begin{tabular}{llcccc}
\hline \multirow{2}{*}{ Seasons } & \multirow{2}{*}{ Treatments } & \multicolumn{2}{c}{ Leaf blast (\%) } & \multicolumn{2}{c}{ Neck blast (\%) } \\
\cline { 2 - 5 } & Conventional & (3WAT) & (5 WAT) & (7 WAT) & (9 WAT) \\
\hline \multirow{2}{*}{ Dry } & Reduced Pesticides & 0 & $5.25 \mathrm{a}$ & $11.25 \mathrm{a}$ & $4.74 \mathrm{a}$ \\
& Bio IPM & 0 & $4.42 \mathrm{a}$ & $11.75 \mathrm{a}$ & $4.51 \mathrm{a}$ \\
\multirow{3}{*}{ Wet } & Conventional & 0 & $4.75 \mathrm{a}$ & $9.69 \mathrm{a}$ & $2.65 \mathrm{~b}$ \\
& Reduced pesticides & 0 & $3.38 \mathrm{~A}$ & $11.25 \mathrm{~A}$ & $4.70 \mathrm{AB}$ \\
& Bio IPM & 0 & $4.05 \mathrm{~A}$ & $12.81 \mathrm{~A}$ & $15.50 \mathrm{~A}$ \\
& & $0.30 \mathrm{~A}$ & $9.94 \mathrm{~A}$ & $3.30 \mathrm{~B}$ \\
\hline
\end{tabular}

Note: numbers followed by same symbols in same column and same seasons are not significantly different according to Tukeys test at $\mathrm{p}<0.05$

Table 5. Growth of paddy rice in three pests management techniques

\begin{tabular}{llcccc}
\hline $\begin{array}{l}\text { Growing } \\
\text { seasons }\end{array}$ & Treatment & $\begin{array}{c}\text { Plant height }(\mathbf{c m}) \\
(\text { 6WAT) }\end{array}$ & $\begin{array}{c}\text { Root length }(\mathbf{c m}) \\
(\text { 6WAT) }\end{array}$ & $\begin{array}{c}\text { Max tiller numbers } \\
(\text { 6 WAT) }\end{array}$ & $\begin{array}{c}\text { Productive tiller } \\
\text { number (8 WAT) }\end{array}$ \\
\hline Dry & Conventional & $54.00 \mathrm{a}$ & $20.73 \mathrm{a}$ & $27.23 \mathrm{~b}$ & $15.45 \mathrm{~b}$ \\
& Reduced Pesticides & $42.65 \mathrm{a}$ & $20.18 \mathrm{a}$ & $35.58 \mathrm{a}$ & $18.75 \mathrm{~b}$ \\
& Bio IPM & $54.81 \mathrm{a}$ & $22.78 \mathrm{a}$ & $26.40 \mathrm{~b}$ & $21.75 \mathrm{a}$ \\
Wet & Conventional & $61.13 \mathrm{~A}$ & $25.88 \mathrm{~A}$ & $27.20 \mathrm{~B}$ & $14.15 \mathrm{~A}$ \\
& Reduced Pesticides & $64.25 \mathrm{~A}$ & $26.56 \mathrm{~A}$ & $24.05 \mathrm{~B}$ & $13.45 \mathrm{~A}$ \\
& Bio IPM & $66.25 \mathrm{~A}$ & $32.00 \mathrm{~A}$ & $31.31 \mathrm{~A}$ & $19.28 \mathrm{~A}$ \\
\hline
\end{tabular}

Note: Numbers followed by same symbols in same column and same seasons are not significantly different according to Tukeys test at $\mathrm{p}<0.05$

\section{Discussion}

The use of Bio IPM technology has an effect on increasing soil fertility. Soil microbial abundance is an indicator of soil fertility and its health (Bai et al. 2018; Maron et al. 2018; Lori et al. 2017). Soil health refers to the ecological processes on the ground running well. Fertile soil has a high abundance of soil microbes. In a cropping system, microbial abundance is influenced by season, soil type, and plant type (Lori et al. 2017).
Soil types, plant species among treatments in this study is the same, so the difference in abundance, especially phosphate solubilizing bacteria is mainly caused by the treatment of pest management techniques. The difference between Bio IPM, conventional, and reduced pesticides was, the two later treatments have no application of straw, manure, PGPR, and endophyte. Eliminating all types of pesticides and application of straw, compost leads to an increase in soil microbes, especially total soil bacteria and 
phosphate solubilizing bacteria. Amendment of rice straw has been reported to increase total soil bacteria and phosphate solubilizing bacteria without any significant effect on total soil fungi (Son et al. 2008). PGPR application which contains phosphate solubilizing bacteria supposed to be has a minor effect on soil microbes. Interestingly, Bio IPM had no significant effect on the phosphate solubilizing bacteria in wet season, presumably because high waterlogging would adversely affect the life of soil bacteria (Qiu et al. 2013). Finally, it can be stated that Bio IPM improves soil microbiology by increasing total soil bacteria and phosphate solubilizing bacteria.

However, various pest control techniques such as conventional control, reduced pesticides, and Bio IPM do not affect the abundance of soil fungi. Riyanti et al. (2015) observed that the treatment of rice straw increases the abundance of phosphate solubilizing bacteria on organic manure more than 5 tons per ha, but the study did not find the abundance of bacteria and fungi. This shows that the total abundance of soil fungi is not sensitive to the amendment of organic matter. In addition, most of the time rice fields are flooded and due to this reason, anaerobic conditions occur, which do not support the growth of most soil fungi (Qiu et al. 2013). Another effect of Bio IPM technology is enhancing the abundance of total leaf endophytic fungi and Nigrospora sp., especially in the early rice growth stages. This is because fungicides are not used at all, and endophytic Nigrospora is also used in this technique. The abundance of the main endophytic fungi in rice stems was Nigrospora sp., influenced by the treatment of pest control techniques. The abundance of total endophytic fungi and abundance of Nigrospora sp. confers the resistance to brown planthopper (Mawan et al. 2015) and diseases (Sucipto et al. 2015). The antifungal ability of Nigrospora sp. against various plant pathogenic fungi have been reported by Song et al. (2016).

Bio IPM is proven to be an effective treatment in controlling blast disease of rice, especially neck blast, and increases certain variables of growth i.e. the maximum number of tillers and the number of productive tillers. Growth and disease control is a complex mechanism affected by Bio IPM. It is a set of technologies consisting of optimization of NPK fertilization, compost tea application, straw amendment, application of microbial agents (PGPR and Nigrospora), and zero use of pesticides. Each of these components has been individually reported to increase rice growth and control plant diseases. The use of straw compost and potassium fertilizer has been observed to suppress blast disease and increase rice growth (Syarif et al. 2017). The use of PGPR (Handoko et al. 2009, Lucas et al. 2009), and endophytic Nigrospora are also able to control rice diseases (Song et al. 2016). On the other hand, compost tea is also been reported to promote plant growth and control of rice blast disease (Suwandi et al. 2016). On the other side, glyphosate herbicide associated with physiological changes and microbial community changes, enhancing plant disease infection (Johal and Huber 2009, Martinez at al. 2018). Straw amendment can minimize harmful effects of pesticides on soil ecological processes. Rahmansyah et al. (2009) reported that increasing the availability of nitrogen and phosphorous nutrients by curbing the instability of urease and protease is due to pesticide application. In addition, rice straw amendment can promote plant growth by enhancing available nitrogen through increasing biological nitrogen fixation (Ladha et al.1987).

In this study, it has been demonstrated that Bio IPM controls neck blast and increases the growth of rice plant, especially maximum tillers amount. The mechanism of Bio IPM enhances plant growth and controls blast disease in general, due to the interaction of two mechanisms i.e. enhancement of supporting factors and decrease in disrupting factors for plant growth and microbe abundance. Supporting factors for plant growth and vigor, and the abundance of soil microbes, are dependent on potassium, compost tea, PGPR, endophytes, and amendment of straw+manure treatment. Herbicide application is a disrupting factor for plant vigor (Ahsan et al 2019), while disrupting factors for soil microbes and endophytic fungi are the use of herbicides (Martinez et al. 2018), insecticides (Das and Mukerjee 2000), and fungicides (Lada et al 1987; Lori et al 2017)

In the present study, it has been observed that Bio IPM technology increases the rice growth, controls blast disease, and also has a positive impact on the microbiological quality of paddy soils and rice endophytic communities. Therefore, it is a key component in sustainable rice production.

\section{ACKNOWLEDGEMENTS}

The authors thank the Directorate General of Higher Education of the Ministry of Education and Culture, through LPPM IPB University, Bogor, Indonesia who has funded the research on the development of integrated rice intensive bio-intensive pest management technology. The authors would also like to thank Karmo for field assistance.

\section{REFERENCES}

Ahsan N, Lee DG, Lee KW, Alam I, Lee SH, Bahk JD, Lee BH. 2008. Glyphosate-induced oxidative stress in rice leaves revealed by proteomic approach. Plant Physiol Biochem 46 (12): 1062-1070. DOI: 10.1016/j.plaphy.2008.07.002

BPS-Statistics Indonesia. 2019. Statistical Yearbook of Indonesia. BPSStatistics Indonesia

Bai Z, Caspari T, Gonzalez MR, Batjes NH, Mäder P, Bünemann EK, De Goede R, Brussaard L, Xu M, Ferreira CSS, Reintam E, Fan H, Mihelič R, Glavanh M, Tóth Z. 2018. Effects of agricultural management practices on soil quality: a review of long-term experiments for Europe and China. Agric Ecosys Environ 265 (2018): $1-7$

Biswas S, Kundu DK, Mazumdar SP, Saha AR, Majumdar B, Ghorai AK, Ghosh D, Yadav AN, Saxena AK. 2018. Study on the activity and diversity of bacteria in a New Gangetic alluvial soil (Eutrocrept) under rice-wheat-jute cropping system. J Environ Biol 39 (1): 1-8. DOI: $10.22438 / \mathrm{jeb} / 39 / 3 / \mathrm{MRN}-523$ 379-386

Center for Agricultural Data and Information System Secretariat GeneralMinistry of Agriculture. 2015. Statistic of climate, crop pest and climate change impact 2012-2015. Ministry of Agriculture, Jakarta.

Das AC, Mukherjee D. 2000. Soil application of insecticides influences microorganisms and plant nutrients. Appl Soil Ecol 14 (1):55-62 
Johal, GS, Huber, DM. 2009. Glyphosate effects on diseases of plant. Eur J Agron 31 (3): 144-152. DOI: 31. 144-152. DOI 10.1016/j.eja.2009.04.004.

Handoko S, Soekarno BPW, Wiyono S. 2009. Compost enrichment with Trichoderma harzianum dan plant growth-promoting rhizobacteria to promote growth and induce resistance against blast disease. 0 . Prosiding Seminar Nasional Perlindungan Tanaman; Bogor, 5-6 Agustus 2009.

Hidayat F, Khamidi T, Wiyono S. 2010. Pengetahuan sikap dan tindakan petani Tegal dalam penggunaan pestisida dan kaitannya dengan tingkat keracunan terhadap pestisida. Jurnal Bumi Lestari 10 (1): 112. [Indonesian]

Husnain MT, Wakatsuki T, Masunaga T. 2010. Field assessment of nutrient balance under intensive rice-farming systems, and its effects on the sustainability of rice production in Java Island, Indonesia. J Agric Food Environ Sci 4 (1):1-11.

International Rice Research Institute. 2002. Standard Evaluation for Rice Research. IRRI, Los Banos.

Istiaji B, Santoso S, Wiyono S, Triwidodo H. 2012. Key factor analysis of brown planthopper Nilaparvata lugens (Stal) (Hemiptera: Delphacidae) outbreak in Klaten Regency, Indonesia. Journal ISSAAS 18: 193-268.

Juma EOA, Musyimi DM, Opande G. 2018. Enumeration and identification of rhizospheric microorganisms of sugarcane variety CO 421 in kibos, Kisumu County, Kenya. Journal of Asian Scientific Research. 8 (3): 113-127 DOI: 10.18488/journal.2.2018.83.113.127

Ladha JK, Tirol-Padre A, Daroy MLG, Punzalan G, Watanabe I. 1987 The effects on $\mathrm{N}_{2}$ fixation $\left(\mathrm{C}_{2} \mathrm{H}_{2}\right.$ reduction), bacterial population and rice plant growth of two modes of straw application to a wetland rice field. Biol Fertility Soils 5 (2): 106-111.

Lori M, Symnaczik S, Mäder P, De Deyn G, Gattinger A. 2017. Organic farming enhances soil microbial abundance and activity - A metaanalysis and meta-regression. PLoS ONE 12 (7): e0180442DOI: 10.1371/journal. pone.0180442.

Lucas JA, Ramos B, Montes F, Ojeda JS. 2009. Use of two PGPR strains in the integrated management of blast disease in rice (Oryza sativa) in Southern Spain. Field Crops Research 114 (3): 404-410. DOI: 10.1016/j.fcr.2009.09.013

Martinez DA, Loening UL, Graham MC. 2018. Impacts of glyphosatebased herbicides on disease resistance and health of crops: a review. Environ Sci Eur 30: 2. DOI: 10.1186/s12302-018-0131-7.

Maron PA, SarrA, Kaisermann A, LévêqueJ, Mathieu O, Guigue J, Karimi B, Bernard L, Dequiedt S, Terrat S, Chabbi A, Anjard L. 2018. High microbial diversity promotes soil ecosystem functioning. Appl Environ Microbiol 84 (9): e2738-17. DOI: 10.1128/AEM.02738-17.

Mawan A, Buchori D, Triwidodo H. 2015. Effects of endophytic fungi on the biology and the statistic demographic of brown planthopper Nilaparvata lugens Stál (Hemiptera: Delphacidae). Jurnal Entomologi Indonesia. 12 (1): 11-19. DOI: 10.5994/jei.12.1.11

Oerke EC, Dehne HW. 2004. Safeguarding production-losses in major crops and the role of crop protection. Crop Protection 23 (4): 275285.

Park, Hong-Hyun, Joon-Ho Lee. 2009. Impact of pesticide treatment on an arthropod community in the Korean rice ecosystem. J Ecol Field Biol 32 (1): $19-25$.
Qiu S, Wang MK, Wang F, Chen J, Xiaoyan L, Qinghua Li, Lin C. 2013. Effects of open drainage ditch design on bacterial and fungal communities of cold waterlogged paddy soils Shanlian. Brazilian J Microbiol. 44 (3): 983-991.

Rahmansyah M, Antonius S, Sulistinah N. 2009. Phosphatase and urease instability caused by pesticides present in soil improved by grounded rice straw. ARPN J Agric Biol Sci 4 (2): 56-62.

Riyanti S, Purnamawati H, Sugiyanta. 2015. The effect of application organic fertilizer and biofertilizer with compound fertilizer (NPK) reduction on the availability of nutrient and soil microbe population of paddy at second cultivate season in Karawang, West Java. Bul Agrohorti 3 (3): 330-339.

Settle WH, Ariawan H, Tri Astuti E, Cahyana W, Sri Lestari A, Pajarningsih, Hakim AL, Hindayana D, Sartanto. 1996. Managing tropical rice pests through conservation of generalist natural enemies and alternative prey. Ecology 77 (7): 1975-1988.

Song JJ. Pongnak W, Soytong K. 2016. Antifungal activity of endophytic fungi from palm trees against coffee anthracnose caused by Colletotrichum coffeanum. Intl J Agric Technol 12 (3): 527-539.

Son TTN, Man LH, Diep CN, Thu TTA, Nam NN. 2008. Bioconversion of paddy straw and biofertilizer for sustainable rice-based cropping systems. Omonrice 16: 57-70.

Sucipto I, Munif A, Suryadi Y, Tondok ET. 2015. Exploration of endophytic fungi from lowland rice as a biocontrol agent of blast disease in lowland rice. Jurnal Fitopatologi Indonesia 11 (6): 211-218. DOI: $10.14692 /$ jfi.11.6.211

Suliasih, Widawati S. 2005. Isolation and identification of phosphate solubilizing and nitrogen-fixing bacteria from soil in Wamena Biological Garden, Jayawijaya, Papua. Biodiversitas 6 (6): 175-177. DOI: $10.13057 /$ biodiv/d060307

Suryanarayanan TS, Vijaykrishna D. 200I. Fungal endophytes of aerial roots of Ficus benghalensis. Fungal Divers 8: 155-161

Syarif, AS. Wiyono S, Sukarno BPW, Purwoko BS. 2017. Role of rice straw compost and potassium in controlling blast disease of paddy rice in South Sulawesi, Indonesia. Intl J Sci Basic Appl Res 36 (4): 244-254

Suwandi, Hamidson H, Muslim A. 2016. Suppression of panicle blast by rice straw compost extract. Jurnal Fitopatologi Indonesia 12: 104-108 DOI: $10.14692 /$ jfi.12.3.104

Townsend GR, Heuberger JW. 1943. Methods for estimating losses caused by diseases in fungicide experiments. Plant Dis Rep 27 (17): 340-343.

Widodo, Wiyono S. 2012. Biofungicide powder formulation of double activated materials of Pseudomonas fluorescens PG 01 and Bacillus polymixa BG 25. Jurnal Ilmu Pertanian Indonesia (JIPI) 17 (3): 180185

Wiyono S, Prakoso B, Santoso S. 2012. Diversity of sheath endophytic fungi and the role in protection of rice against brown planthopper, Nilaparvata lugens (Stål) (Homoptera: Delphacidae). J ISSAAS 18: 193-268.

Wiyono S, Widodo, Triwidodo H. 2014. Managing outbreak of rice pest and diseases in fragile agroecocystem by biointensive integrated pest management. Risalah Kebijakan Pertanian dan Lingkungan 1 (2): 5 10. [Indonesian] 